\title{
A BRIDGE OVER THE PAST: PREHISTORIC SETTLEMENT TRACES, A ROMAN CEMETERY, AND A STRUCTURE CONNECTING PERIODS ON THE DANUBE BANK New results of the archaeological excavation connected to the Graphisoft Park extension project
}

\author{
Barbara Hajdu ${ }^{1}$ - Farkas Márton Tóth ${ }^{2}$ \\ Hungarian Archaeology Vol. 9 (2020), Issue 4, pp. 14-22. doi: https://doi.org/10.36338/ha.2020.4.4
}

\section{As archaeologists of the Budapest History Museum, we conducted a rescue excavation connected to the Graphi- soft Park extension project between September and mid- December in 2019, and from the end of March to mid- August in 2020, by the Danube in Óbuda (Old Buda), near Aquincum, in District 3 of Budapest (Fig. 1). The excava- tion uncovered parts of a complex, multi-period, and, in some places, multi-layer site. Although it had been known and researched for a long time, the site still had many excit- ing, unforeseen surprises, which we briefly present below. ${ }^{3}$}

In the area east of Aquincum Civil Town, the first graves were discovered in the $1830 \mathrm{~s}$, and further rescue excavations were led by Bálint Kuzsinszky towards the end of the 19th century (KUZSINSZKY 1892). At the beginning of the 20th century, excavations became more frequent in the area due to the construction of the Óbuda Gasworks. During these surveys a Roman period pottery workshop and over 100 burials were brought to light. The first systematic excavations, led by Paula Zsidi, began in 1996 when the construction of the Graphisoft Park started (Zsidi 1997).

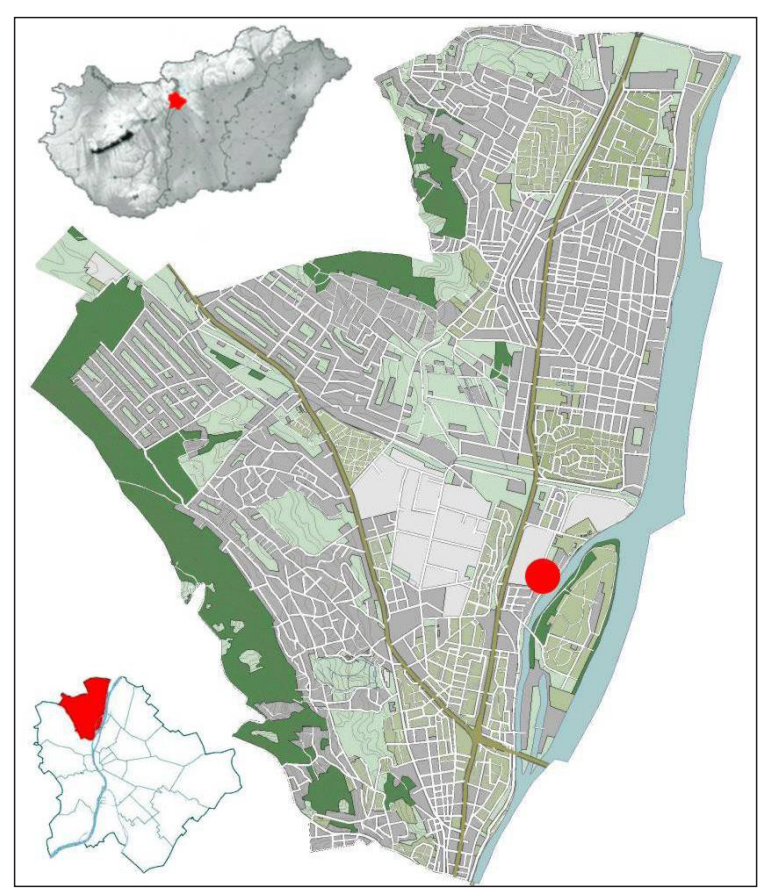

Fig. 1. Location of the 2019-2020 excavations on the maps of Hungary, Budapest, and District 3 (by Farkas Márton Tóth) The fieldwork continued under the leadership of Gábor Lassányi until 2017 (LASSÁNYI \& SzEREDI 2020). ${ }^{4}$ Thanks to these excavations, a better understanding was gained of the Roman period workshop east of the Civil Town, as well as of the multi-period prehistoric site and the Roman period cemetery with, by now, over 1500 burials further south. In 2019 and 2020 we again had an opportunity to excavate at three locations (Fig. 2), during which 398 stratigraphic units were uncovered in an area of $5923 \mathrm{~m}^{2}$.

\footnotetext{
Archaeologist, BHM Aquincum Museum, Department of Ancient History. E-mail: hajdu.barbara@aquincum.hu

2 Archaeologist, Deputy Head of Department, BHM Aquincum Museum, Department of Prehistory and the Migration Period. E-mail: tothfarkasmarton@gmail.com

3 We hereby thank machine operator Attila Arany and forewoman Piroska Vígh (SB Dynamic Ltd.) and the staff of the companies providing manual earth-moving services (Salisbury Ltd., Club Sixty Ltd.) for their indispensable work during the excavation. We are also grateful to our colleagues Orsolya Láng, Adrienn Vukics, Flóra Lamm, and Noémi Fuchs, as well as to the archaeological technicians of the BHM Archaeological Excavation Projects Office (especially Zsófia Kelemen, Levente Virágh and Nikolett Schmidt) for their contribution. Furthermore, we would like to thank István Fábián, Tibor Kovács and Sándor Imre-Horváth for the surveying of the excavation, and László Rupnik (Institute of Archaeological Sciences, Eötvös Loránd University) for the drone photogrammetry of the 2019 results . We would like to thank our consultants, Gábor Lassányi and Paula Zsidi, for supporting our work with their invaluable advice. We would also like to express our gratitude to Graphisoft Park (especially Marianna Drágán, Roland Huber and János Kocsány) for their support and help in the excavation and preservation of these unique remains. We are indepted for the translation of the manuscript to Zoltán Quittner and Katalin Sebők.

4 Preliminary reports of the results of earlier excavations at the Gasworks and Graphisoft Park were published in the journal Aquincumi Füzetek. For a more detailed summary of previous research see LASSÁNYI \& SzEREDI 2020.
} 


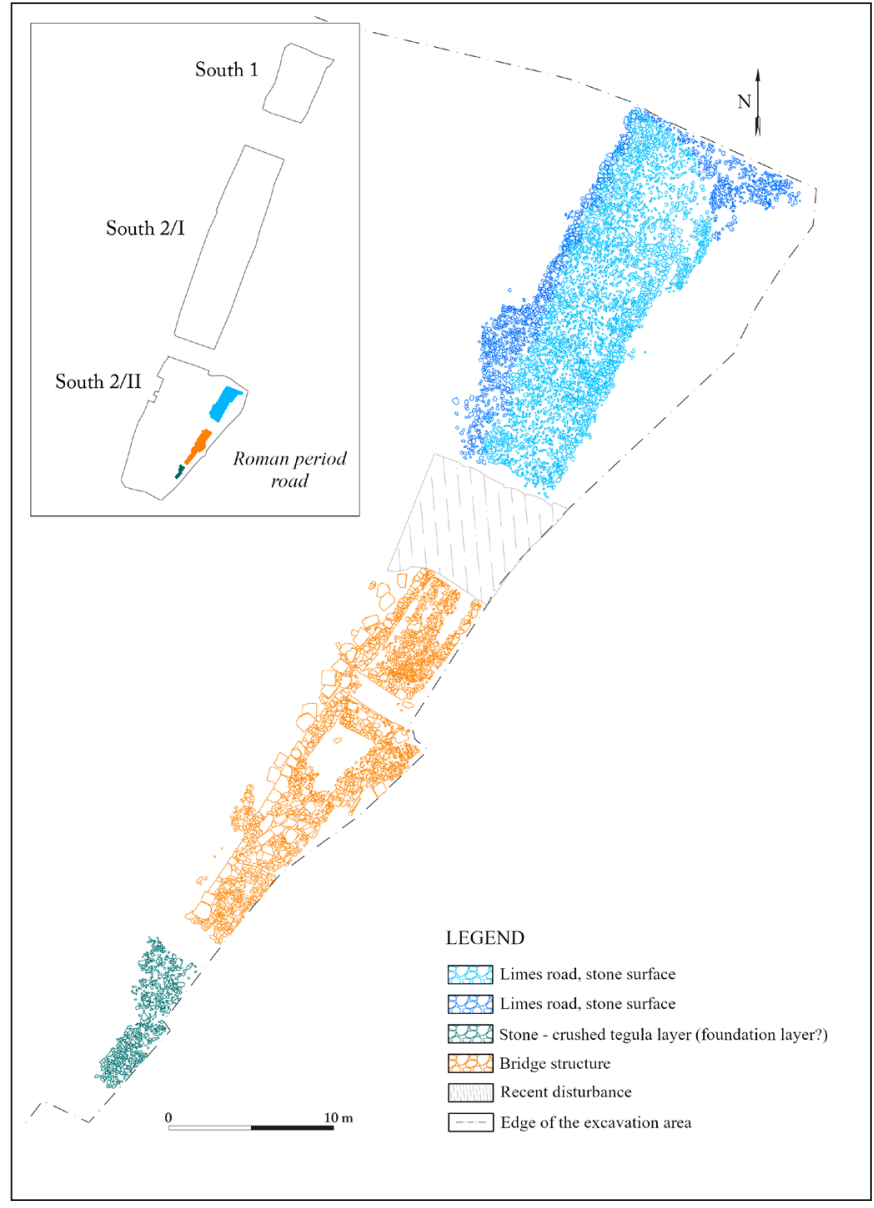

Fig. 2. Survey drawing of the excavated Limes road section (by Gergö Juhász, Edina Poptiuc, Lowpoly 360 Ltd.) and the comprehensive plan of the 2019-2020 excavation connected with the Graphisoft Park extension project (by István Fábián and Krisztián Kolozsvári)
THE GEOGRAPHICAL ENVIRONMENT

The diverse and mosaic-like archaeological topography of the site, and the intensive occupation of the area since the Neolithic have been fundamentally shaped by natural geomorphological characteristics: the levees and alluvial cones standing out from the floodplain by the Danube at Óbuda. The excavated areas are on the right bank of the Danube, opposite the Óbuda Island, in the southwestern part of the housing estate built for Gasworks administrators in 1914. The archaeological site was discovered in the southern excavation area, underneath a recent fill layer which constitutes the modern surface. The site is situated on the riverbank and in the partially filled-up bed of an early Holocene branch of the Danube, oriented N-NW / S-SE, between a narrow levee along the branch and a wider prominence running towards the southwest. Based on recent environmental-historical research, there was a system of adjoining watercourses in this former floodplain area between the Csillaghegy Ditch, the so-called Mocsárosdülő and the Óbuda Island (PÁlL, Tо́тH \& Sipos 2017; Tо́тн et al. 2019).

Between the Copper Age and the drier, warmer climate phase of the Roman period (1st-3rd centuries $\mathrm{AD}$ ), the area can be reconstructed as an only intermittently waterlogged and rarely inundated, marshy floodplain, supplied in part by large floods of the Danube, and in part by meteoric water from the foothills. Its connection to the Danube was likely in the vicinity of the southern edge of the excavated areas. Based on our observations, this deeper terrain was interspersed by alluvial deposits, caused by climatic changes in the Roman period (GRÜLL 2017, 64-66) and by the rising discharge of the Danube, and increasingly frequent extreme floods. A sterile, thick sediment layer, which was observed during the transection of the former bed, divided the Roman layers into two. The levee, formed by river sediment deposits, became a defining feature in terms of the archaeological topography during the late Roman period.

The northern part of the excavation area shows a different picture. Here the prehistoric and Roman archaeological features appeared on the southwestern slope of a former sandy prominence running south from the mouth of the Aranyhegy stream. This part of the site is, therefore, more closely connected in terms of geography and archaeological topography with the features uncovered by previous excavations here, prior to the construction of the Graphisoft Park (LASSÁNYI \& SZEREDi 2017).

In order to reconstruct the geomorphological and environmental conditions of the Roman road and bridge as well as their surroundings, samples were taken for physical and geochemical soil analysis (carried out by István Viczián, CsFK Geographical Institute). Samples were also taken for OSL (optically stimulated luminescence) measurements in order to date changes in the sediment layers and the landscape around the former Danube branch (these measurements were undertaken by György Sipos, University of Szeged). Hopefully, the analysis of these features and their immediate and wider environment, as well as the changes they underwent, will provide a significantly more detailed picture of the last two millennia of this stretch of the Danube bank. 
Barbara Hajdu - Farkas Márton Tóth $\bullet$ A Bridge Over the Past

\section{TRACES OF PREHISTORIC OCCUPATION}

In the southern excavation area (South 2/Phase I-II), the earliest traces of occupation were vessel fragments dated to the middle Neolithic and the Copper Age. No closed features, that could have been easily dated to this period, were observed. The early Bronze Age and late Iron Age (La Tène D) occupation was evidenced by stray finds (e.g. a Celtic

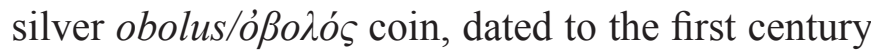
BC; Fig. 3), ${ }^{5}$ as well as by a few disturbed settlement features. A contracted inhumation burial without any grave goods can be hypothetically dated to the early Bronze Age, based on the burials discovered at sites further to the north, associated with the Csepel group of the Bell Beaker Culture (LASSÁNYI 2011, 36-39). The lack of prehistoric features and the scatteredness of the finds are most likely due to a highly intensive land use during the Roman period, which resulted in a significant disturbance of layers from earlier periods.

In the northern excavation area (South 1), too, vessel fragments from the middle Neolithic represent the earliest occupation. In the majority of the features uncovered here, however, we found artefacts from the early and middle Bronze Age. Settlement features from this period, primarily roundish storage and refuse pits of various sizes and depths, represented the subterranean traces of prehistoric occupation. An intact jug from the early Bronze Age (Fig. 4), came to light presumably from a secondary context, from the humus layer above the subsoil, and a few stray bronze finds may be considered grave goods from disturbed burials. The last prehistoric occupation phase observed at the site is represented by a few pottery fragments of the late Bronze Age Urnfield Culture.

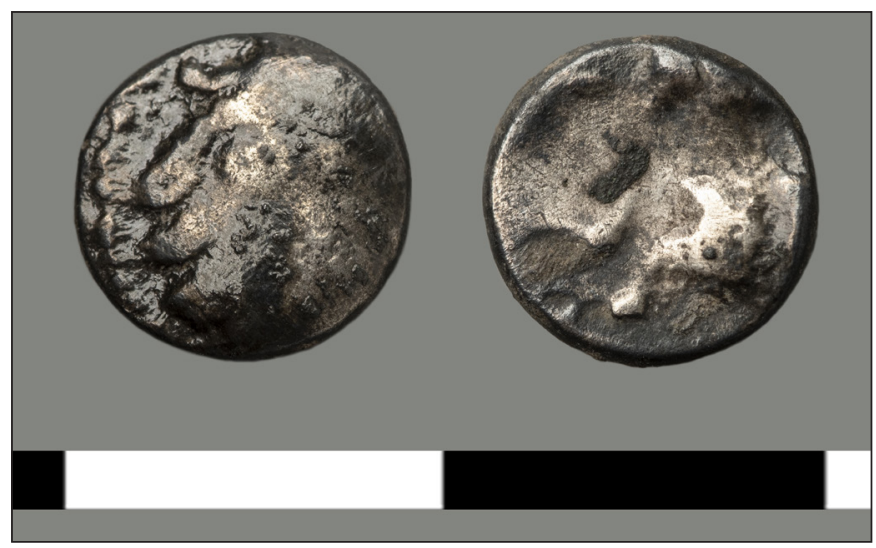

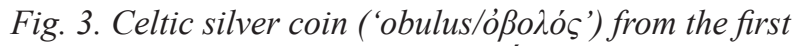
century BC (conservation by Gábor Újvári, photograph by Nóra Szilágyi; BHM Aquincum Museum)

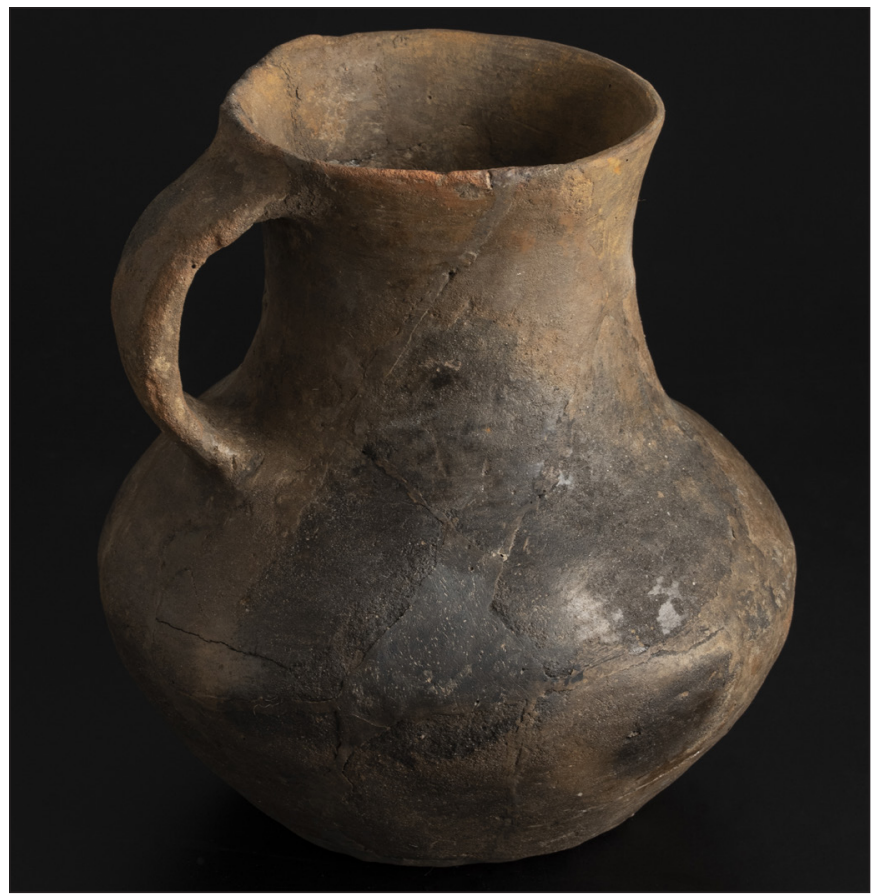

Fig. 4. Jug likely belonging to an early Bronze Age burial from the second half of the $3 \mathrm{rd}$ millennium $B C$ (conservation by Katalin Heincz, photograph by Nóra Szilágyi; BHM Aquincum Museum)

\section{REMAINS OF THE ROMAN OCCUPATION}

The eastern cemetery of the Aquincum Civil Town extended to all three excavation areas. The necropolis was established outside the city, to the east-southeast, and was in use between the late 1st and the 5th centuries AD. In addition to the early cremation burials, inhumations were also present in the cemetery; this custom became more prevalent from the 2nd century AD.

In the southern part of the cemetery, at least two Roman period phases could be identified. Based on the preliminary analysis of the findings, large clay extraction pit complexes were dug here between the 1 st and 2nd centuries AD. Afterwards, there was a change of function, and from the 2 nd -3 rd centuries $\mathrm{AD}$, this

\footnotetext{
We hereby thank Melinda Torbágyi (Hungarian National Museum) for her help in identifying and dating the coin.
} 
Barbara Hajdu - Farkas Márton Tóth $\bullet$ A Bridge Over the Past

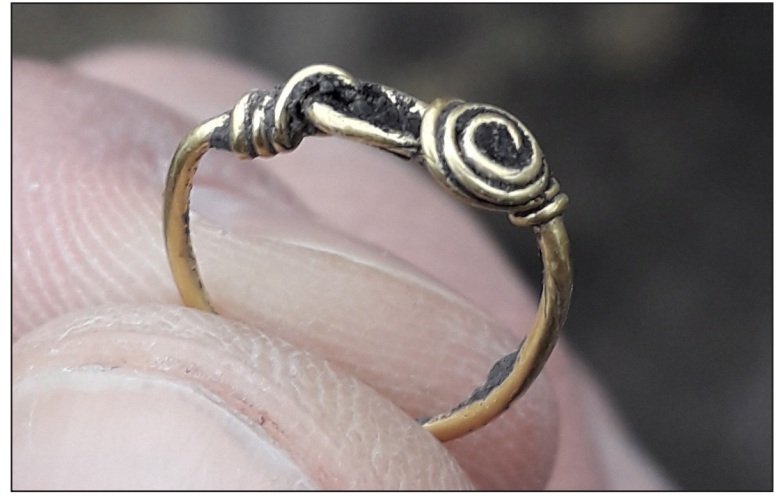

Fig. 5. Golden earring from a Roman period cremation burial (photograph by Farkas Márton Tóth) area started to be used as a burial ground by residents of the Civil Town.

During the excavation we found 76 graves from the Roman period with diverse rites and orientations. Thanks to the closeness of the Danube, and the soggy, muddy environment, some of the wooden planks placed on top of the deceased were preserved in a good condition; these provided invaluable data regarding the burial customs of the Roman period. The most common grave goods were pottery and glass vessels, lamps, coins, fibulas, iron studs from shoes (caliga), as well as various pieces of jewellery. Of these, the most precious find was a golden earring from a cremation burial (Fig. 5).

The high number of stray finds is due primarily to the work of our colleague, metal detectorist Lajos Sándor, who discovered over two hundred metal objects. Of these, a gilded bulb-headed fibula associated with late Roman military attire, and a bronze hook indicating fishing in the riverside and its floodplain environment, found at the edge of the muddy fill of the riverbed, are of considerable significance.

One evidence for the continuous use of the area following the Roman period is the shallow ditch running from south to north, unearthed in the south-eastern corner of South 2/Phase II, which yielded pottery fragments dated to the Avar period. ${ }^{6}$

\section{THE LIMES ROAD}

This year's excavation season had some great surprises in store even compared to earlier results, with finds which can be considered sensational from both an expert and a non-specialist perspective. Southeast of the aforementioned cemetery section we uncovered a previously unknown stretch of the Limes road, which was of fundamental strategic importance in protecting the frontiers of the Roman Empire (Fig. 2). The Pannonian section of the road connected the military installations and settlements along the Danube, playing a significant role in ensuring the flow of supplies and reinforcements.

The creation of the Ripa Pannonica, a frontier defence system along the Danube in the territory of today's Hungary can be dated to the Flavian period. In the territory of Aquincum it was established in the final quarter of the 1st century AD (Borhy \& Szabó 2015, 110). The Limes road, which crossed Aquincum, in the time of the 1st and 2nd centuries AD ran along the path of the modern-day Szentendrei Road (ZsIDI 2002, 135, 138). Later, by the start of the 3rd century AD its path was moved to east of the Civil Town, closer to the Danube (Zsidi 2002, 138-139; VISY 2003a, 39) (Fig. O). Like other imperial roads, during the Roman period the Limes road was built and maintained by the army.

The road section uncovered by the excavation was 64 metres long, running in a N-S direction, built of large

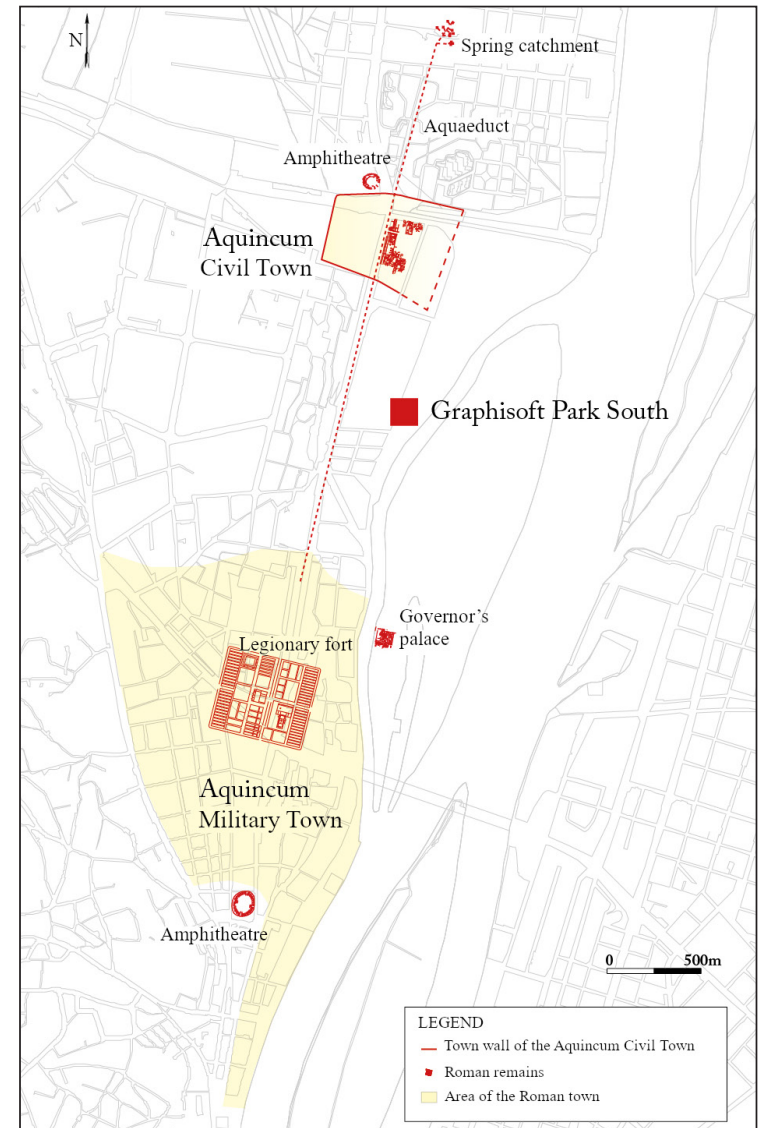

Fig. 6. The excavation site on the map with the topography of Roman Aquincum

6 We hereby thank Boglárka Mészáros (BHM Aquincum Museum) for identifying the fragments. 


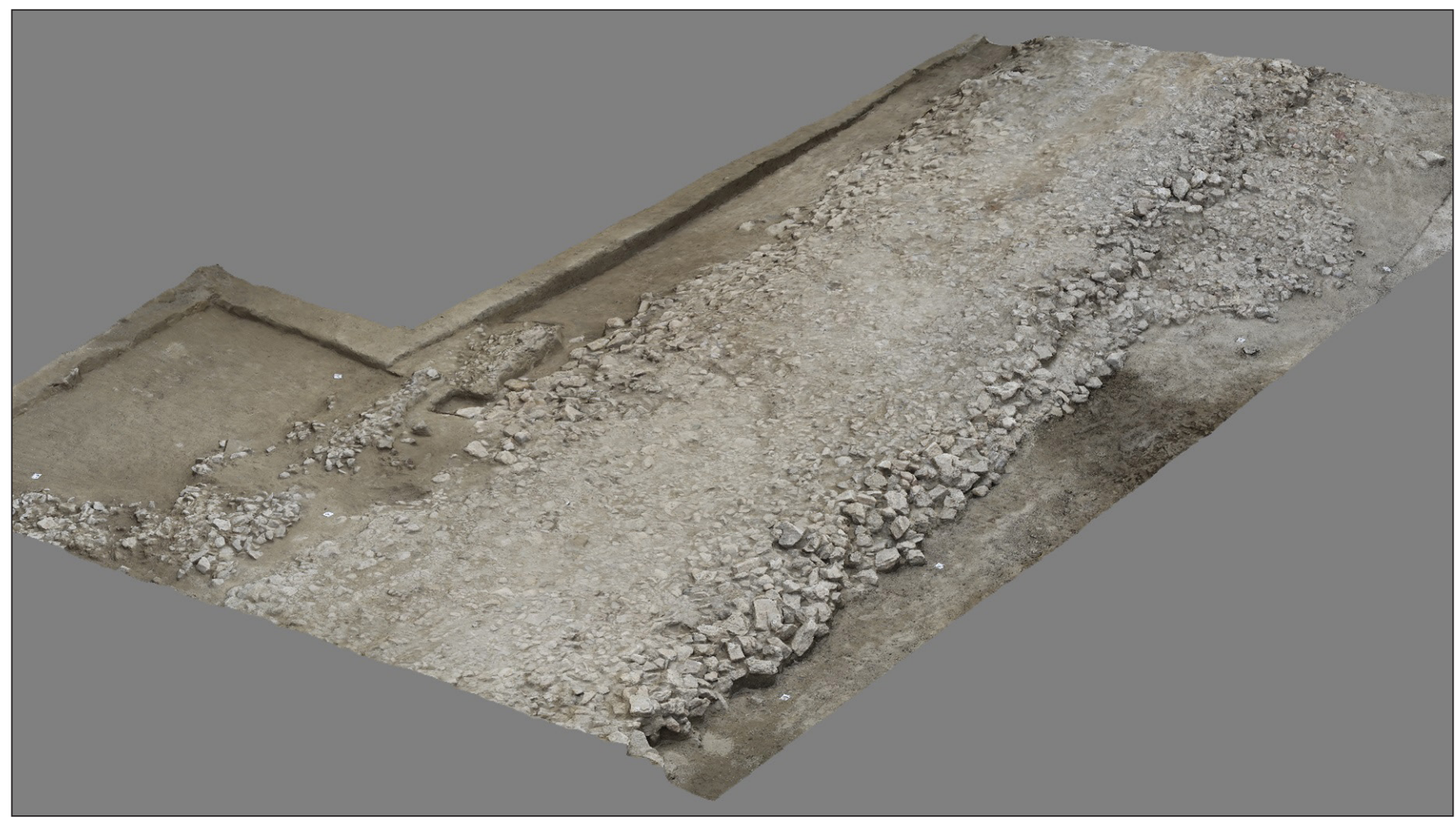

Fig. 7. Three-dimensional image of the northern section of the Limes road (by Balázs Gyurics, Gergő Juhász, Lowpoly 360 Ltd.)

stones; its width reached 10-12 metres in some places (Fig. 7). The excavated stretch is one of the bestpreserved ones among the known sections of the Limes road in Pannonia. In the northern part, closest to the Civil Town, this sturdy structure consisted of several stone layers reaching a total thickness of around 70 $\mathrm{cm}$, which is typical mostly of important military bases and large towns (VISY 2003b, 133). In the case of extra-mural, rural contexts similar to the topographical position of our road, we usually find unpaved roads with pebbles and gravel.

On the road surface we could observe the traces of cartwheels and potholes fixed with construction debris. This is not surprising, given that on a daily basis dozens of carts could have used this highly important strategic and commercial route, and troops, too, used the road to travel between forts. The wear signs caused by frequent use and the road repairs indicated already at the beginning of the excavation that the route, through constant maintenance, could have been in use for at least centuries.

The road's northern and central stretches were crossed by modern sewers, but these provided an excellent opportunity to study its structure in cross sections. We could observe a characteristic trait of Roman road building, where first the central axis of the road was marked with large stones, ${ }^{7}$ on which in a consecutive phase the layers of the road were built. For optimal drainage, the builders sought to make the road's surface convex. Usually, they dug two parallel ditches to drain the water on either side of the road. Here, however, due to the local circumstances this was not necessary, as this stretch of the road was built on a levee rising above its surroundings. Rain and water from the inundations of the Danube could drain freely down the side of the levee. During the Roman period roads in swampy, waterlogged areas were often placed on prominences, which, in certain circumstances, could also be created artificially (VISY 2003a, 45).

North of the present excavation, on the site of the former Gasworks the excavations led by Paula Zsidi had found two road sections with a similar orientation to ours, also built on a prominence along the Danube bank: one in 2000 (Zsidi 2001, 78) and one in 2002 (ZsIDI \& REMÉNYI 2003). These, however, were not paved with stones. Their dating is uncertain, so they may only conditionally be connected with the Limes road found this year.

We hereby thank András Bödőcs (ELTE Institute of Archaeological Sciences) for his help in analysing the road structure. 
Barbara Hajdu - Farkas Márton Tóth $\bullet$ A Bridge Over the Past

Several cross sections were created on the excavated road section and the levee underneath to examine its structure and chronology. In one of these a reused terracotta antefix fragment (roof ornament) was found, together with fragments of a so-called 'model lighthouse' used for decorating chimneys, dated to the 2nd century $\mathrm{AD}$, among the stones. The dating of the construction to the 3rd century AD is evinced by a silver denarius of Severus Alexander (222-228) found on the road surface, trodden between the stones. ${ }^{8}$

That the role of this section of the Limes road remained significant also during the centuries following the Roman period - for some 1200 years altogether ${ }^{9}$ - is indicated by some medieval and early modern cart parts and iron horseshoes found along and on its surface. After playing its role in protecting the borders during the Roman period, there is evidence for its increased importance during and after the Árpád period, presumably connected to the communication between Buda and Visegrád. This is confirmed by coins of Géza II (1130-1162) and Louis I (1342-1382), as well as a small group of coins minted by Ferdinand I (1526-1564), found in the immediate vicinity of the road.

\section{THE BRIDGE STRUCTURE}

South of the place where the modern sewer cuts through the northern road section, below the paved road surface we found walls built on large beams with a rectangular cross-section jointed together, held by piles placed in rows. Upon unearthing this structure, which was difficult to interpret at first, layer by layer we came closer to solving its complex puzzle. Finally, it became clear that the stone walls with a timber foundation belonged to a bridge connected with the road (Fig. 8). The bridge had been built over a 1.5-metrewide aperture perpendicular to the road, leading to the Danube. The road section north of the bridge was paved with small stones, while larger stones were used to pave the section to the south. In the latter section, the road was flanked on both sides by sturdy, rectangular stone slabs. We found a number of stone pieces from the bridge's arch in a secondary context, as these were reused during the 18-19th centuries for a brick-

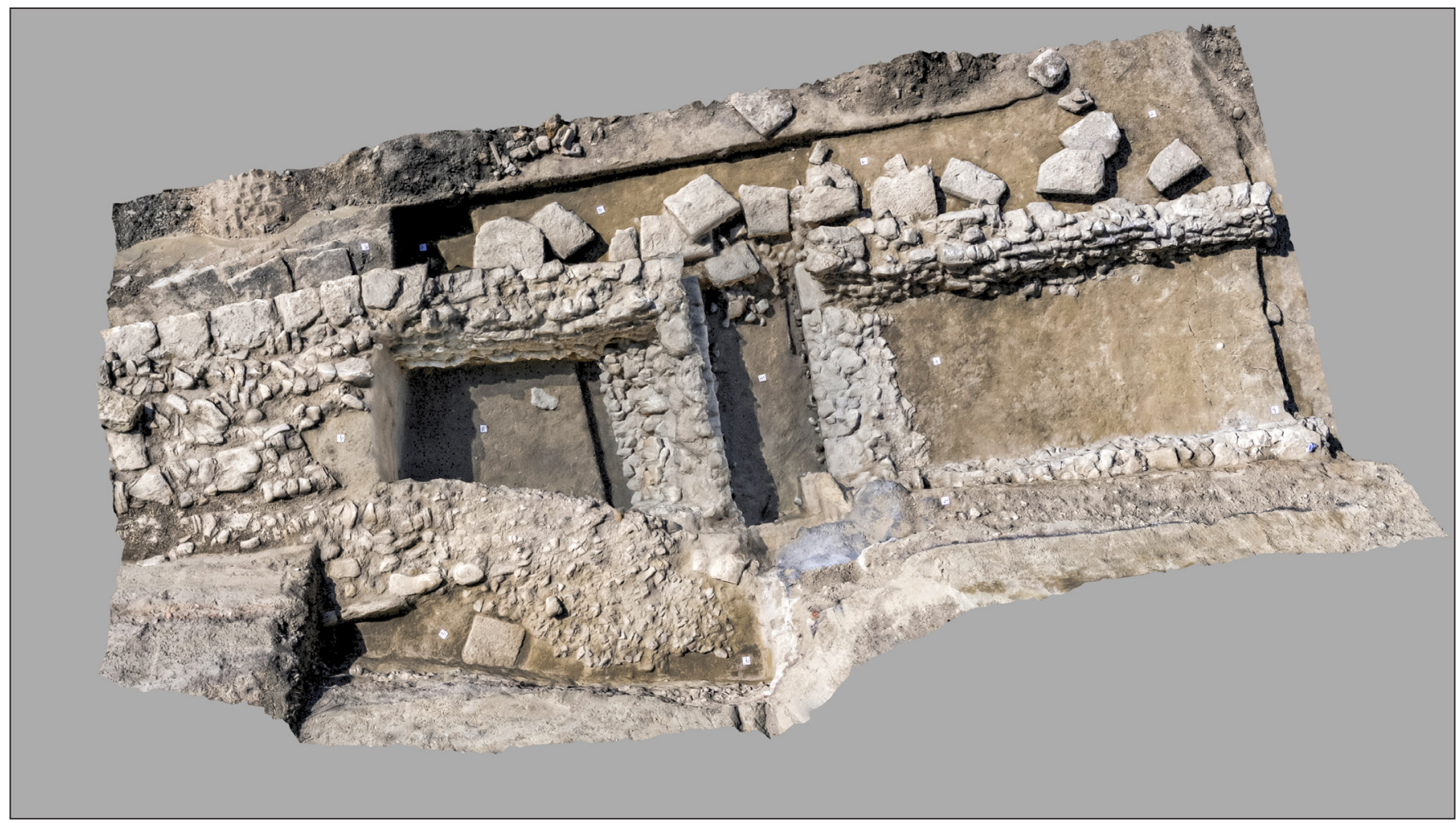

Fig. 8. Three-dimensional image of the bridge structure, flanked by supporting walls, and the central section of the Limes road (by Balázs Gyurics, Gergö Juhász, Lowpoly 360 Ltd.)

8 We hereby thank Lajos Juhász (ELTE Institute of Archaeological Sciences) for identifying the coin.

9 A number of roads in Hungary remained in use for centuries following the Roman period (see PETÖ 2014). 
vaulted culvert built above the structure. The line of the lower part of the original arch appeared in the eastern section wall of the bridge aperture (culvert) marking the edge of a layer caused by the filling-up of the aperture while the structure was still standing. Hence, it may be possible to reconstruct the bridge's arch. Its closest architectural analogy is a bridge abutment by Mozaik Street, in the south of the recently excavated road section, partially excavated in 1978-79. The abutment was built using a similar pile-wall technique, where a row of piles ran along a foundation built of ashlars (Zsidi 1999, 258).

The carved and jointed oak beam structures, serving as foundation for the walls supporting the arch of the bridge aperture and the stone walls to the north and south, as well as the rows of piles rammed into the ground to reinforce them were found in an

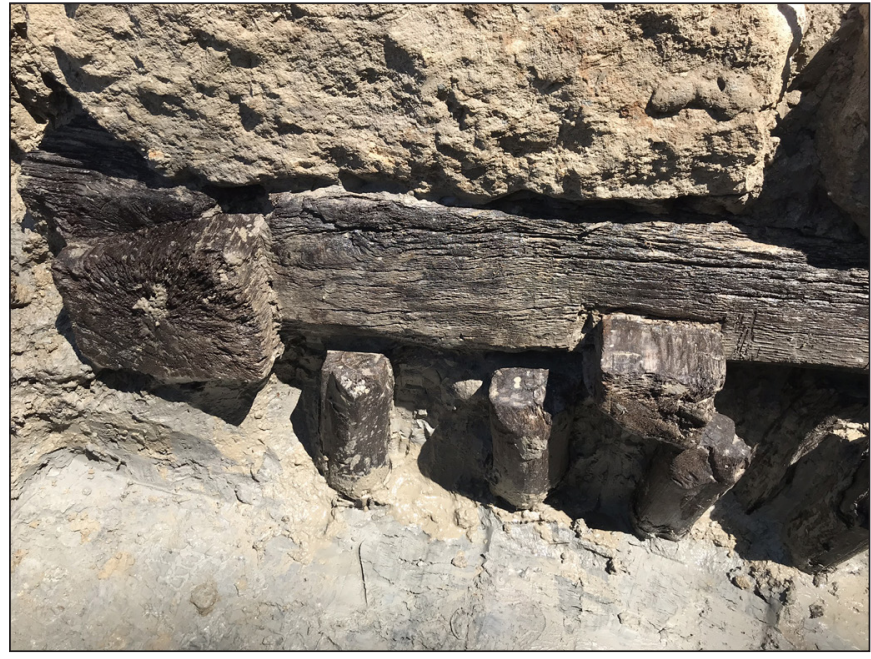

Fig. 9. Detail of the jointed beam structure and row of piles on the northern side of the bridge aperture (photograph by Barbara Hajdu) especially good condition thanks to the anoxic environment caused by the floodplain sediment (Fig. 9). The special construction technique of the bridge built on a levee between the Danube and its former subchannel was necessary so that in this floodplain area the inundations should not undermine the road or destroy the bridge.

Based on conventional radiocarbon dating of samples from the timber structures, the wooden beam foundation for the abutment north of the aperture can be dated to the Roman period (210-345 AD). One of the piles to the south of the aperture belonged to the period between 1482 and 1645, while a beam in the foundation of the western side wall of the southern abutment could be dated between 1402-1459 (analysed by György Sipos, University of Szeged). The results indicated that after the condition of the bridge, built as part of the Limes road in the Roman period, deteriorated due to continuous use and perhaps floods, it was partially repaired and reinforced at the southern abutment during the late medieval or early modern period. The iron chisel used for woodworking, found in one of the soil layers of the disturbed levee, perhaps belonged to this renovation.

To refine the results of the carbon isotope dating, dendrochronological samples were taken with the help of András Grynaeus (Hungarian Dendrological Laboratory). Based on the xylotomic analysis, for the timber structures the builders chiefly used common oak, and for some of the piles they used durmast oak. It was not possible to absolute date the dendrochronological sequences, but their comparison confirmed that the timber structures on the eastern side of the northern and southern abutment were made in the same period, and that these parts were not affected by later renovation. The repairs were likely made necessary by the decay of the bridge, heavily exposed to two-way water flow and larger floods, and by the continued importance of the route and a need for further usability. The partial renovation was probably necessary because the western part of the structure was more exposed to the destructive force of the water gushing from the floodplain back into the Danube's main bed.

For documenting the road and the bridge we used the most state-of-the-art methods at our disposal. Hence, in addition to traditional archaeological documentation, we also took orthophotographs by drone in various phases of the excavation, and recorded the uncovered structure using photogrammetric methods (Gergő Juhász, Lowpoly 360 Ltd.). We also complemented our documentation by a laser scanner survey (Zoltán Kibédy, CÉH Planning, Developing and Consulting Inc.).

Recognising the exceptional significance of the excavated structure, and also in line with the regulations of the heritage protection authority, the Graphisoft Park altered its previous construction plans, and the structure was covered and reburied. Although, for technical reasons, the structure could not be exhibited on site, its documentation using state-of-the-art methods will enable us to present it virtually. 
Barbara Hajdu - Farkas Márton Tóth $\bullet$ A Bridge Over the Past

We are also planning to present the results of the 2019-2020 excavations connected with the Graphisoft Park expansion project in a temporary exhibition of the Aquincum Museum to the general public in the near future.

\section{RECOMMENDED READINGS}

H. Kérdő, K. \& Schweitzer, F. (2014). Aquincum. Ancient Landscape - Ancient Town. Budapest: MTA FKI.

Lóki, R. \& Szabó M. (2011). A limes-út (The limes road). In Visy Zs., Szabó M., Lóki R. \& Priskin A. (eds.), A Danube Limes Project régészeti kutatásai 2008-2011 között (The Danube Limes Project Archaeological Research between 2008-2011) (pp. 101-106). Pécs: PTE Régészet Tanszék.

Visy, Zs. (ed.) (2003a). The Roman Army in Pannonia. An Archaeological Guide of the Ripa Pannonica (Translated from Hungarian by G. Bertók). Budapest: Teleki László Foundation.

Visy, Zs. (2003b). The Ripa Pannonica in Hungary (Translated from Hungarian by G. Bertók). Budapest: Akadémiai Kiadó.

Zsidi, P. (ed.) (2005). Kincsek a város alatt: Budapest régészeti örökségének feltárása, 1989-2004. Kiállitás a Budapesti Történeti Múzeumban 2005. május 27 -augusztus 20. (Treasures under the city: Survey of the archaeological heritage of Budapest, 1989-2004. Temporary exhibition at the Budapest History Museum 27 May - 20 August 2005.) Budapest: Budapesti Történeti Múzeum.

Zsidi, P. (ed.) (2017). Kincsek a város alatt - Újdonságok a múltból. Budapest régészeti örökségének feltárása 1867 / 2005-2015. Idöszaki kiállitás a BTM Vármúzeumban 2017.04.12.-2017.09.17. Kiállítási vezetö és katalógus. (Treasures under the city - Novelties from the past. Revealing the archaeological heritage of Budapest 1867 / 2005-2015. Temporary exhibition in the Budapest History Museum - Castle Museum. April 12 - September 17, 2017. Exhibition guide and catalogue.) Budapest: Budapesti Történeti Múzeum.

Hungarian Limes Association. http://www.ripapannonica.hu (Accessed on 26/10/2020).

\section{BIBLIOGRAPHY}

Borhy, L. \& Szabó, M. (2015). Magyarország története az ókorban: Kelták és rómaiak. [The History of Hungary in Antiquity: The Celts and Romans]. Budapest: L'Harmattan Kiadó.

Grüll, T. (2017). A Római Birodalom gazdasága. [The Economy of the Roman Empire]. Budapest: Gondolat Kiadó.

Kuzsinszky, B. (1892). Római kori temető Aquincumban. [Roman period cemetery in Aquincum]. Archaeologiai Értesitö 12, 446-448.

Lassányi, G. (2011). Kora bronzkori és római kori temetőrészlet feltárása a volt Óbudai Gázgyár déli részén. (Excavation of parts of Early Bronze Age and Roman cemeteries in the southern part of the former Óbuda Gas Factory.) Aquincumi Füzetek 17, 36-51. 
Barbara Hajdu - Farkas Márton Tóth $\bullet$ A Bridge Over the Past

Lassányi, G. \& Szeredi, A. (2017). Ásatások a Graphisoft Park Déli részén (Excavations in the Southern Part of the Graphisoft Park). Aquincumi Füzetek 23, 81-88.

Lassányi, G. \& Szeredi, A. (2020). Feltárások a volt Óbudai Gázgyár északi részén (Excavations in the Northern Part of the Gas Factory in Óbuda). Aquincumi Füzetek 24, 112-120.

Páll, D. G. \& Tóth, F. M. \& Sipos, Gy. (2017). Mocsáros természetvédelmi terület (Budapest III. Kerület) földtudományi vizsgálata [Geoscientific analysis of the Mocsáros natural conservation area (District 3, Budapest)]. Történeti táj - Tájrégészet. Eredmények és perspektívák a magyarországi tájrégészeti kutatásban. Absztrakt kötet. 2017. november 6-7. Magyar Tudományos Akadémia Bölcsészettudományi Kutatóközpont Régészeti Intézet, Budapest, 77.

Petö, Zs. E. (2014). Roman or medieval? Historical roads in the Pilis forest Hungarian Archaeology 3 (3) [2014 Autumn], 1-9.

Tóth, F. M., Páll, D. G., Sipos, Gy., Szilas, G., Viczián, I. \& M. Virág, Zs. (2019). Környezeti változások a Duna egykori mellékága mentén. Interdiszciplináris kutatás Budapest III. kerület, Mocsárosdülőn [Environmental changes along a former subchannel of the Danube. Interdisciplinary research on Mocsárosdülö, Third District of Budapest]. In F. M. Tóth (ed.), MSMO - Öskoros Kutatók XI. Összejövetele - Környezet és ember. Absztrakt kötet (p. 32). Budapest: Budapesti Történeti Múzeum.

Visy, Zs. (ed.) (2003a). The Roman Army in Pannonia. An Archaeological Guide of the Ripa Pannonica (Translated from Hungarian by G. Bertók). Budapest: Teleki László Foundation.

Visy, Zs. (2003b). The Ripa Pannonica in Hungary (Translated from Hungarian by G. Bertók). Budapest: Akadémiai Kiadó.

Zsidi, P. (1997). Szondázó jellegü feltárás az aquincumi polgárvárostól délkeletre (Test excavations carried out southeast of the Aquincum Civil Town). Aquincumi Füzetek 3, 54-57.

Zsidi, P. (1999). Hídfóállás az aquincumi polgárváros és katonaváros között [Bridge abutment between the Civil Town and Military Town of Aquincum]. In Gaál, A. (ed.) Pannoniai kutatások. A Soproni Sándor emlékkonferencia elöadásai (Bölcske, 1998. október 7.) (pp. 257-274). Szekszárd: Wosinszky Mór Megyei Múzeum.

Zsidi, P. (2001). Kutatások az aquincumi polgárvárostól keletre lévő területen (Research in the territory east of the Aquincum Civil Town). Aquincumi Füzetek 7, 76-84.

Zsidi, P. (2002). Transformation of the town structure in the civil town of Aquincum during the Severi (A.D. 193-235). Acta Archaeologica Academiae Scientiarum Hungaricae 53, 131-149. https://doi.org/10.1556/ aarch.53.2002.1-3.6

Zsidi, P. \& Reményi, L. (2003). Duna-parti út részlete és őskori maradványok a polgárvárostól délre (Detail from the road on the Danube bank and prehistoric remains south of the Civil Town). Aquincumi Füzetek 9, $86-94$. 